Article

\title{
The Influence of Aquaculture Effluents on the Prevalence and Biocides Resistance of Opportunistic Pseudomonas fluorescens Bacteria in the Drwęca River Protected under the Natura 2000 Network
}

\section{Iwona Gołaś (iD)}

Department of Water Protection Engineering and Environmental Microbiology, University of Warmia and Mazury in Olsztyn, Prawocheńskiego 1, 10-720 Olsztyn, Poland; iwonag@uwm.edu.pl; Tel.: +48-89-523-45-57

Received: 6 June 2020; Accepted: 7 July 2020; Published: 9 July 2020

\begin{abstract}
The aim of this study was to determine the effect of trout aquaculture effluents on the Drwęca River. The count of opportunistic pathogen Pseudomonas fluorescens (OPPF) in the total Pseudomonas fluorescens population (TPFP) were determined by plating on King B medium and fluorescence in situ hybridization. The resistance of OPPF strains to 12 antibiotics and two disinfectants was evaluated. Significant differences $(p \leq 0.05)$ in OPPF counts were found between seven sampling sites. OPPF counts were highest in samples collected directly downstream from three fish farms. More than $50 \%$ of these isolates demonstrated multiple-drug resistance to ampicillin, mezlocillin, cefotaxime, norfloxacin, tetracycline and two disinfectants (Steridial and chloramine T). Of these, 52\% were resistant to high doses of cefotaxime and norfloxacin (MIC $\geq 256 \mu \mathrm{g} \cdot \mathrm{mL}^{-1}$ ), and $65 \%$ were resistant to the maximum doses of Steridial (MIC Ste $\geq 25 \mathrm{~mL} \cdot \mathrm{m}^{-3}$ ) and chloramine T (MIC Chlor $\geq 20 \mathrm{mg} \cdot \mathrm{L}^{-1}$ ). All OPPF sampled upstream from the farms were sensitive to low concentrations of CTX (cefotaxime) and NOR (norfloxacin) (MIC $\leq 2 \mu \mathrm{g} \cdot \mathrm{mL}^{-1}$ ), Steridial (MIC Ste $\leq 5 \mathrm{~mL} \cdot \mathrm{m}^{-3}$ ) and chloramine $\mathrm{T}$ (MIC Chlor $\leq 2.5 \mathrm{mg} \cdot \mathrm{L}^{-1}$ ). Agglomerative clustering revealed two clusters: strains from samples collected upstream and downstream from trout farms. The results indicate that aquaculture effluents significantly affect the prevalence of biocides resistant OPPF along the river continuum.
\end{abstract}

Keywords: aquaculture; water; opportunistic pathogen P. fluorescens; antibiotic resistance; disinfectants; multi-drug resistance index; minimum inhibitory concentration

\section{Introduction}

Pseudomonas fluorescens bacteria are widespread in natural and anthropogenically altered water environments. They form the natural microbiota of ecosystems in which they play an important role in the decomposition of organic matter, circulation of elements and self-purification processes [1,2]. Some $P$. fluorescens strains show hemolytic activity and are classified as opportunistic $P$. fluorescens pathogens. These strains could be an important causative agent of epizootic diseases in fish, other wild animals, livestock and, consequently, humans [3-5]. Higher concentrations of potentially pathogenic strains in water bodies increases the risk of infection for aquatic organisms and contributes to their spread not only in aquatic ecosystems, but also among humans, livestock and wildlife [6,7].

The effluents evacuated from trout aquacultures into surface water bodies are potential sources of transmission of opportunistic strains that increase microbial counts in aquatic environments. Intensive trout farming increases the contamination of aquatic ecosystems that act as receptacles of effluents [8-11]. The use of high-protein fish feed to maximize weight gains in trout aquaculture promotes the growth and development of various groups, genera and species of bacteria that colonize water and fish. These microorganisms include beneficial microbiota that improve the welfare of fish, as 
well as pathogens and opportunistic microorganisms that thrive within a wide temperature range [4]. The latter group includes opportunistic hemolytic strains of $P$. fluorescens, which are among the most frequently identified epizootic agents in various fish species [5].

Preventive and/or therapeutic measures are required to reduce or inhibit the growth of pathogenic and opportunistic microorganisms. These involve biocidal products such as disinfectants and antibiotics [4,12], which can potentially increase drug-resistance in P. fluorescens and other aquatic organisms. This is supported by the literature where different phenotypes of antibiotic resistance were found in opportunistic $P$. fluorescens strains $[5,13,14]$.

Due to the possibility of antibiotic resistant bacteria transmission from fish farms preventive measures are simultaneously used in freshwater aquaculture to minimize the usage of antimicrobial agents as well as their release into the effluent water. There are some alternative methods that are used to reduce the epidemiological risk in aquacultures.

The membrane technology with ultrafiltration or microfiltration is dedicated to the removal of the fraction of fine and colloidal particle sizes to improve water quality over the period of fish rearing [15]. That way, the nutrient supply per bacterium is reduced and ultimately a competitive environment favoring K-selection of the bacteria in the water may be achieved. Beneficial effect of membrane filtration is the possibility to reduce the probability of uncontrolled growth of pathogens in fish farms and in the effluents discharged from aquacultures [16]. The ultraviolet irradiation (UV) and ozonation can be an effective solution for the antibacterial treatment and disinfection of water or effluents in aquacultures [17]. Without an internal disinfection process, obligated or opportunistic pathogens may accumulate on fish farms and pose the high epidemiological risk for aquacultures and water ecosystems. Some biocides are used as a means of disinfecting aquaculture facilities and cages, in controlling the biofouling phenomenon (antifouling), as well as components prophylactic bath of fish [12,18]. Nevertheless, the selective stress exerted by biocides may favor the existence of bacteria expressing resistance mechanisms and their dissemination. This process could create a potential risk of development of cross-resistance between antibiotics and biocides used in aquacultures [19].

The effectiveness of Steridial, other peracetic acid (PAA) based formulations and chloramine $\mathrm{T}$ has been recognized in the prevention and treatment of fish diseases $[12,20,21]$. The rational selection of different types and doses of these biocidal agents supports treatment and disease prevention in aquaculture by inhibiting or eliminating opportunistic and pathogenic microorganisms from breeding facilities [20,22]. Biocidal agents also inhibit microbial transfer to aquatic environments with the discharged effluents. However, the overuse of antibiotics and disinfectants exerts strong selective pressure on aquatic organisms and aquatic environments, and contributes to the emergence of multi antibiotic-resistant or disinfectant-resistant bacteria in fish and other aquatic animals $[4,6,7]$. As a result, fish farms facilities can directly or indirectly promote vertical and horizontal transfer of resistance in aquatic environments and, consequently, in humans and animals. Therefore, from an ecological and epidemiological point of view, aquatic ecosystems receiving fish farm effluents should be closely monitored for the presence of opportunistic pathogenic bacteria.

The progression of multi-drug-resistant aquatic microorganisms that increase the risk of infection is particularly relevant to water bodies that are nature reserves and receive effluents from different aquaculture systems. The Drwęca River, which belongs to the Natura 2000 network of protected areas, is one of such ecosystems [23].

The aim of this study was to determine the effect of aquaculture effluents on the prevalence and biocides resistance of opportunistic pathogens P. fluorescens (OPPF) in the upper course of the Drweeca River, which constitutes an aquatic and ichthyological reserve and an ecosystem of considerable environmental importance. The research hypothesis was verified based on: (i) the counts of OPPF and their percentage in the total P. fluorescens population (TPFP), (ii) an analysis of the resistance phenotypes of OPPF isolates to commonly used antibiotics and disinfectants, (iii) the efficacy of different biocides (minimum inhibitory concentration-MIC) against OPPF. 


\section{Materials and Methods}

\subsection{Study Area and Sampling Sites}

The Drweca River, a right-bank tributary of the Vistula River, is a strongly meandering lakeland river with a length of $207.2 \mathrm{~km}$ and an average slope of $0.41 \%$. The river channel is highly diverse. The entire river belongs to the Drwęca River Nature Reserve, which was established to protect the aquatic environment and fish populations, in particular trout, salmon, sea trout and vimba bream habitats [24]. Drweca is the longest ichthyological reserve in Poland with an area of 444.38 ha, and it belongs to the Natura 2000 network of protected areas in the European Union established under the Habitats Directive (92/43/EEC) [23]. The Drwęca River Valley (code PLH280001) covers an area of 2369.6 ha. The major sources of point pollution reaching the Drweca River include household and sewage and wastewater as well as post-production water. This unique ecosystem is directly affected by surface runoffs carrying pollutants from the river's agricultural catchment area and outflows from three fish farms [14].

Samples for microbiological analyses were collected along a 15-kilometer-long segment in the upper course of the Drwęca River, which receives effluents from three moderately intensive, commercial rainbow trout farms (Figure 1): a Broodstock Farm in Czarci Jar, and two salmonid farms in Rychnowska Wola. In the studied farms, salmonids are fed complete pelleted diets and are reared in natural and concrete ponds. The above implies that all essential nutrients are supplied with feed. Despite the fact that all facilities are properly maintained and operated, they pose the greatest risk of environmental pollution in this section of the river $[25,26]$.

Effluents from the studied fish farms are discharged directly to the Drweca River, which is why water samples were collected from seven sampling sites in specific locations on the river (Figure 1):

- $\quad$ Sampling site I-control site located around $2 \mathrm{~km}$ downstream from the river source;

- Sampling site II-water intake for fish farm No. 1 in Czarci Jar with an estimated annual output 10 tons of trout broodstock;

- $\quad$ Sampling site III-directly downstream from the effluent discharge point of fish farm No. 1 in Czarci Jar;

- $\quad$ Sampling site IV-water intake for fish farms No. 2 and 3 in Rychnowska Wola, situated at a distance of $12 \mathrm{~km}$ from sampling site III;

- $\quad$ Sampling site V-directly downstream from the effluent discharge point of fish farm No. 2 in Rychnowska Wola with an estimated annual output of 50 tons market-sized trout from purchased fry;

- $\quad$ Sampling site VI-directly downstream from the effluent discharge point of fish farm No. 3 in Rychnowska Wola with an estimated annual output of 30 tons market-sized trout from purchased fry;

- $\quad$ Sampling site VII-situated at a distance of around $6 \mathrm{~km}$ downstream from fish farms No. 2 and 3.

Water samples were collected in 2005-2006 at six-week intervals, at a depth of 0.3-0.5 m in the center of the river channel along the examined section of the Drweca River. A total of 56 water samples were collected during the study. 


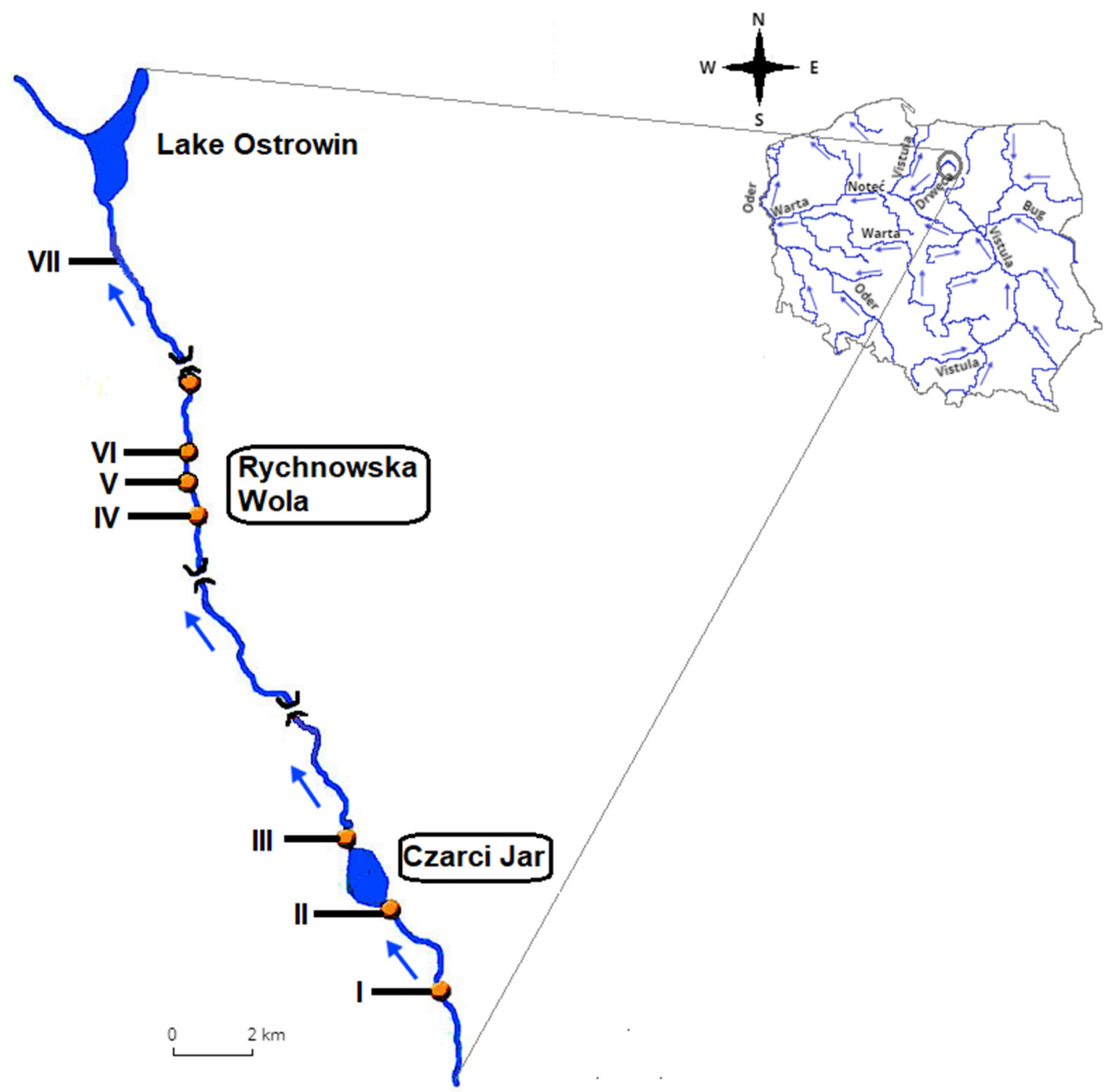

Figure 1. Location of water sampling sites in the upper course of the Drwęca River. Denotations: I-VII—sampling sites; blue arrow-river flow direction.

\subsection{Microbiological Methods}

\subsubsection{Total Pseudomonas fluorescens Population (TPFP) in the Drwęca River}

The quantitative composition of total $P$. fluorescens populations (TPFP) was determined by plating water samples on King B medium and incubating the samples at $30 \pm 2{ }^{\circ} \mathrm{C}$ for $48-72 \mathrm{~h}$ according to APHA guidelines [27]. All determinations were performed in three replicates in the same sample of water. After incubation, colonies showing fluorescence under ultraviolet light were counted and passaged three times on King B medium. P. fluorescens strains were identified by fluorescence in situ hybridization (FISH). Twenty-four-hour broth cultures were fixed with neutralized formaldehyde ( $\mathrm{pH} 7.4$, final concentration of $4 \%$ ) for $4-6 \mathrm{~h}$ at room temperature. The fixed cultures were gently passed through polycarbonate filters $(0.2 \mu \mathrm{m}$ pore size, $47 \mathrm{~mm}$ in diameter) (GTTP, Millipore) and rinsed with $10 \mathrm{~mL}$ of ultrapure water (MQ Millipore). The filters were dried for several minutes at room temperature. The cultures fixed on filters were subjected to the FISH procedure with the use of a Pseudo120 probe (Thermo Fisher Scientific GmbH, Ulm, Baden-Württemberg, Germany) as the specific oligonucleotide probe for the identification of $P$. fluorescens bacteria [28]. The subsequent 
steps of the FISH protocol (including hybridization conditions) and the microscopic quantification of P. fluorescens isolates were described previously by Gołaś et al. [29]. The fluorescence signal of the isolates hybridized with the Cy3-labeled Pseudo120 probe was viewed under a fluorescence microscope (Olympus BX61) equipped with a $\times 100$ oil immersion lens (Olympus Poland, Warsaw, Masovia, Poland), a UV lamp (Olympus Poland, Warsaw, Masovia, Poland), DAPI and CY3 filters (Olympus Poland, Warsaw, Masovia, Poland) and a CCD camera (Olympus) (Olympus Poland, Warsaw, Masovia, Poland). The images were analyzed in the Cell Sence Dimension 2 application (Olympus).

The number of fluorescein-producing colonies that were hybridized with the Pseudo120 probe in the FISH assay [28] were taken into account in the determination of total P. fluorescens populations (TPFP) and expressed as colony-forming units (cfu) per $1 \mathrm{~mL}$ of the analyzed water samples. A total of 200 TPFP strains were isolated from 56 water samples and used in subsequent stages of research.

\subsubsection{Counts of Opportunistic Pathogens P. fluorescens (OPPF) in the Drwęca River}

The counts of OPPF in the 200 isolated TPFP strains were determined based on their proteolytic and hemolytic activity [30] and expressed quantitatively by the R-factor, according to the formula given by Hsu et al. [31]:

$$
\mathrm{R}=\text { total area clear zone }(\mathrm{mm}) / \text { colony area }(\mathrm{mm})
$$

The hemolytic and proteolytic activity of the examined strains was determined according to the methods proposed by Chang et al. [32] and Larsen et al. [33], respectively. The isolates exhibiting high hemolytic and proteolytic activity at $R \geq 4$ were classified as OPPF. The analysis produced 63 OPPF strains, which were then tested for resistance to commonly used antibiotics and disinfectants.

\subsubsection{Antibiotic Resistance of Opportunistic Pathogens P. fluorescens (OPPF)}

The antibiotic resistance of 63 OPPF isolates was analyzed by the disc diffusion method on Mueller-Hinton medium [34]. Twelve popular antibiotics belonging to five classes were used in the analysis: penicillins, fluoroquinolones, sulfonamides, aminoglycosides and tetracyclines. The following standard therapeutic doses of the evaluated antibiotics were used: piperacillin (PRL, $100 \mu \mathrm{g}$ ), ceftazidime (CAZ, $30 \mu \mathrm{g}$ ), ampicillin (AMP, $30 \mu \mathrm{g}$ ), mezlocillin (MEZ, $75 \mu \mathrm{g}$ ), cefotaxime (CTX, $30 \mu \mathrm{g}$ ), ciprofloxacin $(\mathrm{CIP}, 5 \mu \mathrm{g})$, norfloxacin (NOR, $10 \mu \mathrm{g})$, cotrimoxazole (SXT, $25 \mu \mathrm{g})$, gentamicin $(\mathrm{CN}, 10 \mu \mathrm{g})$, tobramycin

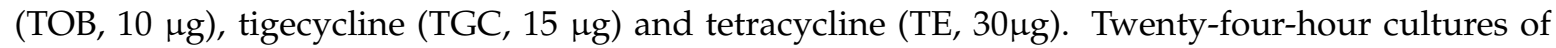
bacterial strains were suspended in $0.85 \%$ saline solution to adjust suspension turbidity to $0.5 \mathrm{McFarland}$. The inocula were plated on Mueller-Hinton agar. After $30 \mathrm{~min}$, discs saturated with antibiotics were applied onto the plates with a dispenser. The plates with antibiotic discs were incubated at $30^{\circ} \mathrm{C}$. The antimicrobial susceptibility of the strains was tested according to the guidelines of the Clinical and Laboratory Standards Institute [35]. The multi-drug resistance of the strains from each sampling site was assessed using the multiple antibiotic resistance (MAR) index. The MAR was calculated based on the resistance of OPPF isolates to at least two antibiotics from different groups, according to the method described by Krumperman [36]. According to Paul et al. [37], natural environments where antibiotics are present sporadically or absent are characterized by MAR $\leq 0.2$, whereas environments with MAR $>0.2$ are at a high risk of antibiotic exposure.

\subsubsection{Minimum Inhibitory Concentrations (MIC) of Antibiotics}

Resistance to standard doses of cefotaxime (CTX, $30 \mu \mathrm{g})$ and norfloxacin (NOR, $10 \mu \mathrm{g}$ ) was most commonly observed in the 63 examined OPPF isolates. Therefore, all OPPF were analyzed for minimum inhibitory concentrations of cefotaxime (MIC SXT) and norfloxacin (MIC NOR) by the gradient agar dilution method [38]. The MIC values of STX and NOR were determined at the following antibiotic concentrations: $2 \mu \mathrm{g} \cdot \mathrm{mL}^{-1}, 4 \mu \mathrm{g} \cdot \mathrm{mL}^{-1}, 8 \mu \mathrm{g} \cdot \mathrm{mL}^{-1}, 16 \mu \mathrm{g} \cdot \mathrm{mL}^{-1}, 32 \mu \mathrm{g} \cdot \mathrm{mL}^{-1}, 64 \mu \mathrm{g} \cdot \mathrm{mL}^{-1}$, $128 \mu \mathrm{g} \cdot \mathrm{mL}^{-1}, 256 \mu \mathrm{g} \cdot \mathrm{mL}^{-1}$ and $512 \mu \mathrm{g} \cdot \mathrm{mL}^{-1}$. Bacterial cultures were steaked onto plates with different 
concentrations of CTX and NOR. The plates were incubated at $28^{\circ} \mathrm{C}$ for $48-72 \mathrm{~h}$, and bacterial growth was examined. The isolates that formed colonies visible to the naked eye were regarded as resistant to a given antibiotic concentration. OPPF strains that did not grow were regarded as sensitive to the tested dose of the antibiotic.

\subsubsection{Resistance of Opportunistic Pathogens P. fluorescens (OPPF) to Disinfectants}

The efficacy of the standard recommended doses of Steridial (Ste) and chloramine T (Chlor) against 63 OPPF strains was analyzed. According to Terech-Majewska et al. [21], the recommended concentrations of Steridial and chloramine $\mathrm{T}$ for the prevention and treatment of fish diseases range from $5 \mathrm{~mL} \cdot \mathrm{m}^{-3}$ to $25 \mathrm{~mL} \cdot \mathrm{m}^{-3}$ of water, and from $2.5 \mathrm{mg} \cdot \mathrm{L}^{-1}$ to $20 \mathrm{mg} \cdot \mathrm{L}^{-1}$, respectively. The minimum inhibitory concentrations of both disinfectants (MIC Ste and MIC Chlor) were determined by the agar gradient dilution method [38]. The following concentrations were used to determine MIC Ste: $5 \mathrm{~mL} \cdot \mathrm{m}^{-3}, 10 \mathrm{~mL} \cdot \mathrm{m}^{-3}, 15 \mathrm{~mL} \cdot \mathrm{m}^{-3}, 20 \mathrm{~mL} \cdot \mathrm{m}^{-3}$ and $25 \mathrm{~mL} \cdot \mathrm{m}^{-3}$. MIC Chlor for the studied isolates was tested at following concentrations: $2.5 \mathrm{mg} \cdot \mathrm{L}^{-1}, 5.0 \mathrm{mg} \cdot \mathrm{L}^{-1}, 10.0 \mathrm{mg} \cdot \mathrm{L}^{-1}$ and $20.0 \mathrm{mg} \cdot \mathrm{L}^{-1}$. The resistance and sensitivity of OPPF isolates to specific concentrations of the tested biocides were determined with the use of the procedure described for MIC CTX and NOR (Section 2.2.4).

\subsection{Statistical Analysis}

Statistical analyses were carried out using the Statistica 13.3 software package (TIBCO Software Inc., Palo Alto, USA). One-way analysis of variance (ANOVA) was used to determine the significance of differences $(p \leq 0.05)$ in: (i) the abundance of TPFP and OPPF between the analyzed sampling sites, (ii) OPPF counts in isolates with specific MIC CTX, NOR, Ste and Chlor values and in river water from different sampling sites. The homogeneity of variances was determined by Levene's test. When Levene's test produced statistically significant results, the verified hypotheses were rejected. The Kruskal-Wallis test, a non-parametric version of classical one-way ANOVA, was then applied [39].

The Student's $t$-test was used to determine statistically significant differences $(p \leq 0.05)$ between the counts of total P. fluorescens populations (TPFP) and of OPPF in samples of water from different sampling sites.

The similarity of sampling sites was determined by cluster analysis with the Bray-Curtis distance measure based on the counts of bacteria with specific MIC CTX, NOR, Ste and Chlor values using PC_ORD 6.08 software. The matrix of agglomerative tree of hierarchical grouping was generated by using the elastic beta method $(\beta=-0.250)$.

\section{Results}

\subsection{Counts of Opportunistic Pathogens P. fluorescens (OPPF) in the Drweca River}

The average counts of OPPF in the upper course of the Drwęca River ranged from several to several dozen $\mathrm{cfu} \cdot \mathrm{mL}^{-1}$ (Table 1$)$. The lowest counts $\left(1 \pm 1 \mathrm{cfu} \cdot \mathrm{mL}^{-1}\right)$ were noted in site I located at a distance of around $2 \mathrm{~km}$ from the river source, and the highest counts $\left(48 \pm 18 \mathrm{cfu} \cdot \mathrm{mL}^{-1}\right.$ and $56 \pm 18 \mathrm{cfu} \cdot \mathrm{mL}^{-1}$ ) were observed in water samples collected in sites V and VI by the effluent discharge points of fish farms No. 2 and 3 in Rychnowska Wola, respectively. Significant $(p=0.000)$ differences in the abundance of TPFP and OPPF between samples collected in different sites were confirmed by the Kruskal-Wallis test. Changes were also observed in the average percentage of OPPF in TPFP along the course of the river. The percentage of OPPF ranged from $11.2 \pm 9.4 \%$ and $11.5 \pm 7.2 \%$ in samples collected in the upper course of the river (sites I and II, respectively) to $84.8 \pm 3.8 \%, 86.5 \pm 8.0 \%$ and $89.5 \pm 3.6 \%$ in samples collected directly downstream from fish farms (site III in Czarci Jar and sites IV and V in Rychnowska Wola, respectively). However, Student's $t$-test revealed significant $(p=0.000)$ differences in OPPF and TPFP counts only between water samples collected in sites I and II in the upper course of the river, and upstream from fishing farm No. 1 in Czarci Jar. 
Table 1. The prevalence and percentage (means and standard deviations) of opportunistic pathogens Pseudomonas fluorescens (OPPF) in the total Pseudomonas fluorescens population (TPFP) in water samples collected in the upper course of the Drwęca River. Statistically significant differences $(p \leq 0.05)$ between water samples collected from sampling sites $(N=56)$ were assessed by the Kruskal-Wallis test (ANOVA, $\mathrm{p}$ ) and Student's $t$-test $(N=8, \mathrm{df}=14)$ and depicted by different letters: ${ }^{\text {a }}$-Kruskal-Wallis test and ${ }^{\mathrm{b}}$-Student's $t$-test.

\begin{tabular}{|c|c|c|c|c|}
\hline \multirow[t]{2}{*}{$\begin{array}{l}\text { Sampling } \\
\text { Sites }\end{array}$} & \multirow[t]{2}{*}{$\begin{array}{l}\text { Number of } \\
\text { Samples }\end{array}$} & $\begin{array}{c}\text { TPFP }^{1} \\
\left(\mathrm{cfu} \cdot \mathrm{mL}^{-1}\right)\end{array}$ & $\begin{array}{c}\mathrm{OPPF}^{2} \\
\left(\mathrm{cfu} \cdot \mathrm{mL}^{-1}\right)\end{array}$ & $\begin{array}{c}\text { Percentage of OPPF in TPFP } \\
(\%)\end{array}$ \\
\hline & & Mean $\pm S D$ & Mean $\pm S D$ & Mean $\pm S D$ \\
\hline I & 8 & $12 \pm 2^{a b}$ & $1 \pm 1^{a b}$ & $11.2 \pm 9.4$ \\
\hline II & 8 & $24 \pm 5^{a b}$ & $3 \pm 2^{a b}$ & $11.5 \pm 7.2$ \\
\hline III & 8 & $45 \pm 11^{a}$ & $38 \pm 8^{a}$ & $84.8 \pm 3.8$ \\
\hline IV & 8 & $36 \pm 6^{a}$ & $16 \pm 5^{a}$ & $42.9 \pm 8.9$ \\
\hline $\mathrm{V}$ & 8 & $56 \pm 21^{a}$ & $48 \pm 18^{a}$ & $86.5 \pm 8.0$ \\
\hline VI & 8 & $62 \pm 19^{a}$ & $56 \pm 18^{a}$ & $89.5 \pm 3.6$ \\
\hline VII & 8 & $34 \pm 9^{a}$ & $19 \pm 5^{a}$ & $57.9 \pm 14.5$ \\
\hline
\end{tabular}

${ }^{1}$ total Pseudomonas fluorescens population; ${ }^{2}$ opportunistic pathogens Pseudomonas fluorescens; ${ }^{a}$ statistically significant differences $(p \leq 0.05)$ in the Kruskal-Wallis test $(N=56) ;{ }^{b}$ statistically significant differences $(p \leq 0.05)$ in Student's $t$-test $(N=8, \mathrm{df}=14)$.

\subsection{Resistance of Opportunistic Pathogens P. fluorescens (OPPF) to the Examined Antibiotics and Disinfectants}

Resistance to standard doses of CTX and NOR was most frequently observed in the 63 OPPF strains isolated from the Drwęca River (Table 2). In the tested group of isolates, in $71.4 \%$ (45 isolates) were resistant to CTX and 52.4\% (33 isolates) were resistant to NOR. Twenty-nine strains (46.0\%) were resistant to AMC, MEZ and TE. Resistance to the remaining chemotherapeutics was observed in eight to 23 strains (12.6-36.5\%). The highest number of OPPF showing resistance to most of the analyzed antibiotics were isolated from water sampled directly downstream from three fish farms (sites III, V and VI). These isolates demonstrated multi-antibiotic resistance (MAR index) and were not sensitive to at least two antibiotics belonging to different groups. The nominal values of MAR were highest in OPPF strains isolated from the samples collected in sites V and VI directly downstream from the fish farms in Rychnowska Wola (MAR 0.47 and 0.51, respectively) relative to the isolates from sites I and II in the upper course of the river (MAR 0.03 and 0.04, respectively).

An analysis of the biocidal efficacy of disinfectants revealed that $100 \%$ of the isolates (nine strains) from samples collected in the upper course of the river (sampling sites I and II) were sensitive to the minimum recommended doses of Steridial $\left(5 \mathrm{~mL} \cdot \mathrm{m}^{-3}\right)$ and chloramine $\mathrm{T}\left(2.5 \mathrm{mg} \cdot \mathrm{L}^{-1}\right)$ (Table 2$)$. Most OPPF strains isolated from water samples collected downstream from fish farms (sites III, $\mathrm{V}, \mathrm{VI}, \mathrm{VII})$ were resistant to the recommended doses of Steridial $\left(5-25 \mathrm{~mL} \cdot \mathrm{m}^{-3}\right)$ and chloramine T $\left(2.5-20 \mathrm{mg} \cdot \mathrm{L}^{-1}\right)$. 
Table 2. Antimicrobial resistance of opportunistic pathogens Pseudomonas fluorescens (OPPF) isolated from the Drwęca River.

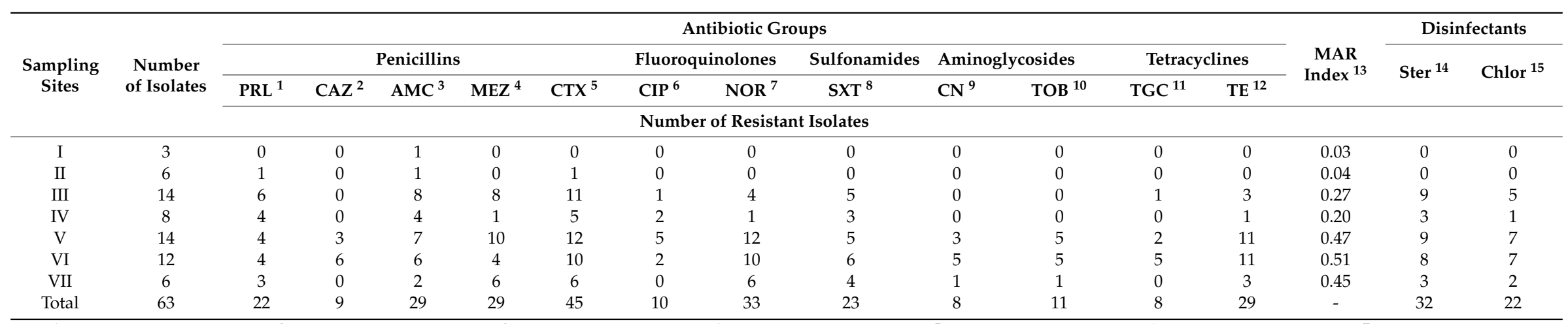

${ }^{1}$ piperacillin (PRL, $\left.100 \mu \mathrm{g}\right) ;{ }^{2}$ ceftazidime (CAZ, $\left.30 \mu \mathrm{g}\right) ;{ }^{3}$ ampicillin (AMP, $\left.30 \mu \mathrm{g}\right) ;{ }^{4}$ mezlocillin (MEZ, $\left.75 \mu \mathrm{g}\right) ;{ }^{5}$ cefotaxime (CTX, $\left.30 \mu \mathrm{g}\right) ;{ }^{6}$ ciprofloxacin $(\mathrm{CIP}, 5 \mu \mathrm{g}) ;{ }^{7} \mathrm{norfloxacin}(\mathrm{NOR}$, $10 \mu \mathrm{g}) ;{ }^{8}$ cotrimoxazole (SXT, $\left.25 \mu \mathrm{g}\right) ;{ }^{9}$ gentamicin (CN, $\left.10 \mu \mathrm{g}\right) ;{ }^{10}$ tobramycin (TOB, $\left.10 \mu \mathrm{g}\right) ;{ }^{11}$ tigecycline (TGC, $\left.15 \mu \mathrm{g}\right) ;{ }^{12}$ tetracycline (TE, $\left.30 \mu \mathrm{g}\right) ;{ }^{13}$ multiple antibiotic resistance (MAR index); ${ }^{14}$ Steridial $\left(\right.$ Ster $\left.\geq 25 \mathrm{~mL} \cdot \mathrm{m}^{-3}\right) ;{ }^{15}$ chloramine T (Chlor $\geq 20 \mathrm{mg} \cdot \mathrm{L}^{-1}$ ); “-“ denotes missing data. 


\subsection{Minimum Inhibitory Concentrations (MIC) of Antibiotics and Disin fectants}

The counts of OPPF showing resistance to the minimum inhibitory concentrations (MIC) of antibiotics (cefotaxime-CTX and norfloxacin-NOR) and disinfectants (Steridial-Ste and chloramine T-Chlor) differed between the tested bactericide and sampling sites (Figure 2). All OPPF isolated from samples collected in sites I and II in the upper course of the Drweca river were characterized by the lowest values of MIC CTX and MIC NOR $\left(\leq 2 \mu \mathrm{g} \cdot \mathrm{mL}^{-1}\right)$. Significantly higher MIC, CTX and NOR values (from 32 to $\geq 512 \mu \mathrm{g} \cdot \mathrm{mL}^{-1}$ ) were noted in strains from water samples collected directly downstream from the fish farms in Czarci Jar and Rychnowska Wola (sites III, V and VI) and around $6 \mathrm{~km}$ from the fish farms (site VII). MIC CTX and NOR value of $64 \mu \mathrm{g} \cdot \mathrm{mL}^{-1}$ was found in $6-20 \%$ and $8-33 \%$ of these isolates, respectively. Resistance to MIC CTX and NOR values of $128-256 \mu \mathrm{g} \cdot \mathrm{mL}^{-1} \mathrm{was}^{-12}$ observed in 25-40\% and 14-20\% strains, respectively. More than 52\% of the 40 OPPF isolates from sites III, V and VI were characterized by MIC, NOR and CTX values of $\geq 256 \mu \mathrm{g} \cdot \mathrm{mL}^{-1}$ (Figure $2 \mathrm{~A}, \mathrm{~B}$ ).

All strains from water samples collected in sites I and/or II in the upper course of the Drweca River were sensitive to the minimum recommended doses of Steridial $\left(5 \mathrm{~mL} \cdot \mathrm{m}^{-3}\right)$ and chloramine $\mathrm{T}$ $\left(2.5 \mu \mathrm{g} \cdot \mathrm{L}^{-1}\right)$. In contrast, the OPPF isolates from the remaining sampling sites were resistant to higher doses of both disinfectants. Out of the 40 strains isolated from water samples collected in sites III, V and VI, resistance to the maximum recommended doses of Steridial $\left(25 \mathrm{~mL} \cdot \mathrm{m}^{-3}\right)$ and chloramine $\mathrm{T}$ $\left(20 \mu \mathrm{g} \cdot \mathrm{L}^{-1}\right)$ was observed in $72-86 \%$ and $65-92 \%$ of the isolates, respectively (Figure 2C,D).

The Kruskal-Wallis test $(N=63, p \leq 0.05)$ confirmed differences in the counts of OPPF resistant to the minimum inhibitory concentrations (MIC) of the tested antibiotics and disinfectants between sampling sites. The differences in the counts of OPPF resistant to cefotaxime (CTX), norfloxacin (NOR), Steridial (Ste) and chloramine T (Chlor) were statistically significant at $p=0.0059, p=0.0035, p=0.0044$ and $p=0.0092$, respectively.

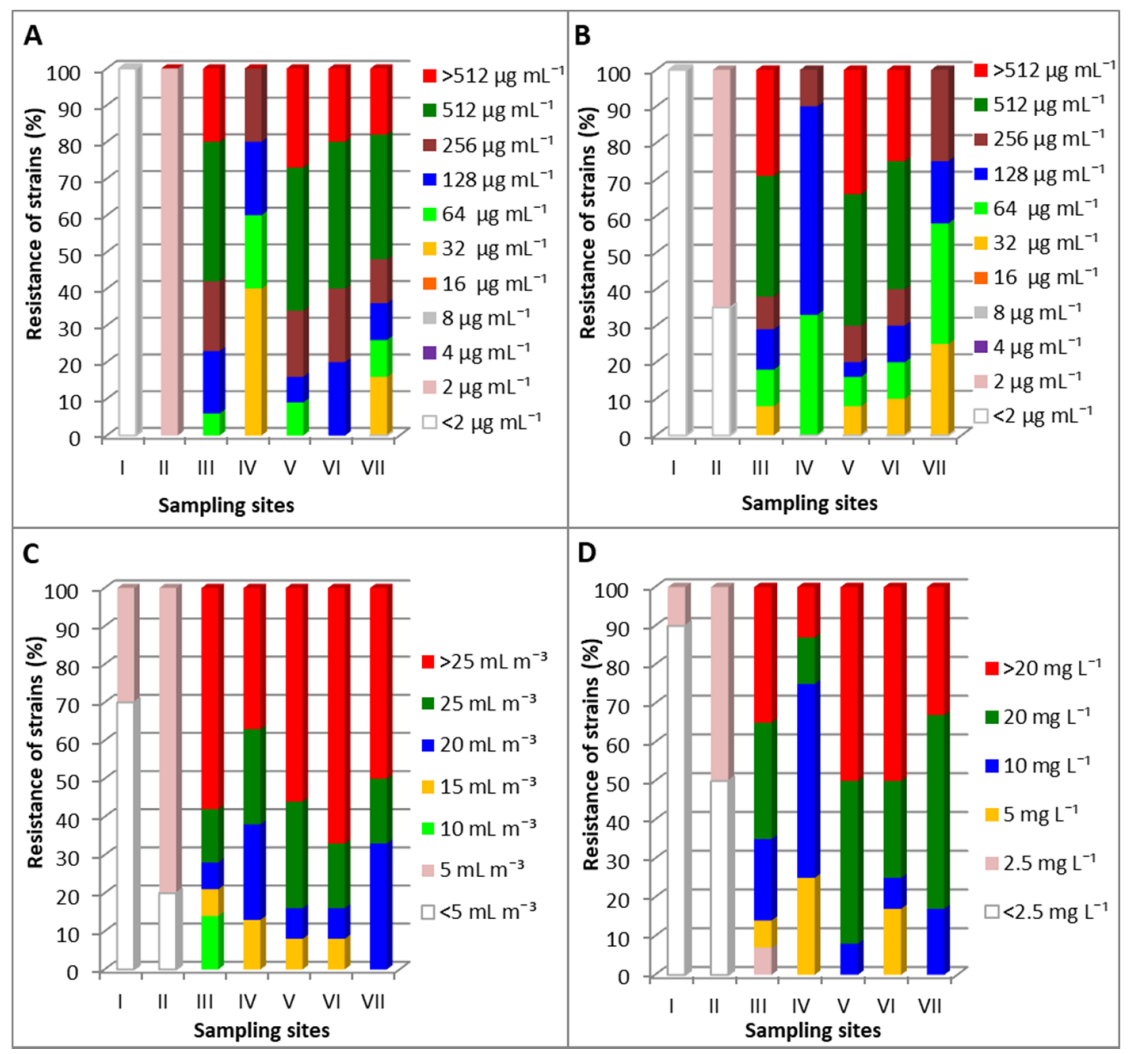

Figure 2. Minimum inhibitory concentrations (MIC) of: (A)—cefotaxime $\left(\mu \mathrm{g} \cdot \mathrm{mL}^{-1}\right)$; (B)—norfloxacin $\left(\mu \mathrm{g} \cdot \mathrm{mL}^{-1}\right) ;(\mathbf{C})$-Steridial $\left(\mathrm{mL} \cdot \mathrm{m}^{-3}\right)$ and $(\mathbf{D})$ —chloramine $\mathrm{T}\left(\mathrm{mg} \cdot \mathrm{L}^{-1}\right)$ for opportunistic pathogens Pseudomonas fluorescens $(N=63)$ isolated from the Drwęca River. 
The similarity of the sampling sites was evaluated by agglomerative clustering analysis with the Bray-Curtis dissimilarity based on the counts of OPPF with specific MIC CTX, NOR, Ste and Chlor values, and it produced two different clusters (Figure 3). The first cluster consisted of strains isolated from water samples collected in sites I and II in the upper course of the river. The second cluster consisted of isolates from sites III-VII which formed a network of interconnected sub-clusters. In the second group, OPPF strains isolated from the effluents discharged by fish farms in Rychnowska Wola (sites V and VI) as well as in samples collected directly downstream from fish farm in Czarci Jar and at a distance of around $6 \mathrm{~km}$ downstream from fish farms No. 2 and 3 (sites III and VII) were the most similar. The samples collected in site IV around $12 \mathrm{~km}$ from the effluent discharge points of fish farm in Czarci Jar (site III) were least similar in terms of OPPF counts with specific MIC CTX, NOR, Ste and Chlor values.

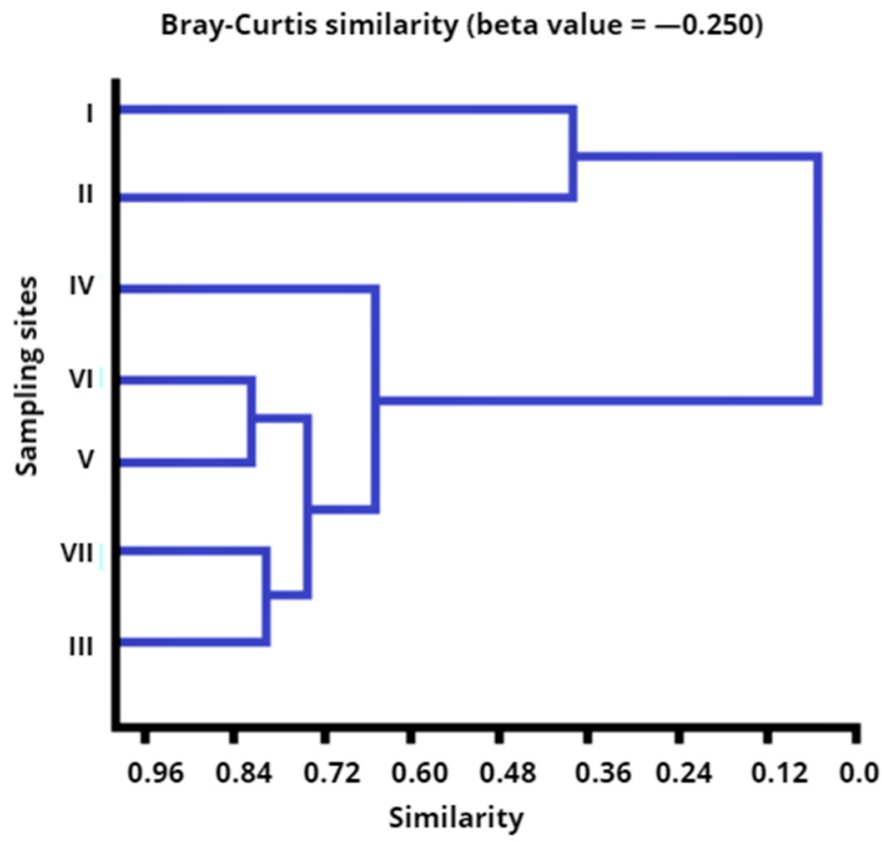

Figure 3. Similarities between sampling sites based on the counts of opportunistic pathogens P. fluorescens (OPPF) responding to different minimum inhibitory concentrations of cefotaxime (MIC CTX: $2 \mu \mathrm{g} \cdot \mathrm{mL}^{-1}, 4 \mu \mathrm{g} \cdot \mathrm{mL}^{-1}, 8 \mu \mathrm{g} \cdot \mathrm{mL}^{-1}, 16 \mu \mathrm{g} \cdot \mathrm{mL}^{-1}, 32 \mu \mathrm{g} \cdot \mathrm{mL}^{-1}, 64 \mu \mathrm{g} \cdot \mathrm{mL}^{-1}, 128 \mu \mathrm{g} \cdot \mathrm{mL}^{-1}, 256 \mu \mathrm{g} \cdot \mathrm{mL}^{-1}$ and $512 \mu \mathrm{g} \cdot \mathrm{mL}^{-1}$ ), norfloxacin (MIC NOR: $2 \mu \mathrm{g} \cdot \mathrm{mL}^{-1}, 4 \mu \mathrm{g} \cdot \mathrm{mL}^{-1}, 8 \mu \mathrm{g} \cdot \mathrm{mL}^{-1}, 16 \mu \mathrm{g} \cdot \mathrm{mL}^{-1}, 32 \mu \mathrm{g} \cdot \mathrm{mL}^{-1}$, $64 \mu \mathrm{g} \cdot \mathrm{mL}^{-1}, 128 \mu \mathrm{g} \cdot \mathrm{mL}^{-1}, 256 \mu \mathrm{g} \cdot \mathrm{mL}^{-1}$ and $512 \mu \mathrm{g} \cdot \mathrm{mL}^{-1}$.), Steridial (MIC Ste: $5 \mathrm{~mL} \cdot \mathrm{m}^{-3}, 10 \mathrm{~mL} \cdot \mathrm{m}^{-3}$, $15 \mathrm{~mL} \cdot \mathrm{m}^{-3}, 20 \mathrm{~mL} \cdot \mathrm{m}^{-3}$ and $25 \mathrm{~mL} \cdot \mathrm{m}^{-3}$ ), and chloramine T (MIC Chlor: $2.5 \mathrm{mg} \cdot \mathrm{L}^{-1}, 5.0 \mathrm{mg} \cdot \mathrm{L}^{-1}$, $\left.10.0 \mathrm{mg} \cdot \mathrm{L}^{-1} 20.0 \mathrm{mg} \cdot \mathrm{L}^{-1}\right)$.

\section{Discussion}

Bacteriological contamination of rivers poses a significant problem by increasing the epidemiological risk associated with the presence of opportunistic or pathogenic bacterial strains in water. The above applies to isolates characterized by high hemolytic activity which induce cytotoxic and proinflammatory responses in epithelial intestinal cells [40] and are resistant to many commonly used antibiotics [41]. This group of bacteria also includes opportunistic pathogens P. fluorescens, which grow rapidly in aquatic environments exposed to pressure from fish aquacultures $[5,22]$. These observations were validated by the present study which investigated the prevalence of OPPF in the upper course of the Drwęca River. The catchment of study area of the Drwęca River was dominated by forest, agricultural areas and small villages [14]. This river ecosystem was directly affected by surface runoffs carrying pollutants from the river's agricultural catchment. Nevertheless, the results of my studies showed the spatial distribution of the studied OPPF isolates differed across sampling sites which were separated by varied distance from trout farms and effluent discharge points on the 
Drwęca River. These findings were confirmed by the Kruskal-Wallis test, which revealed significant differences $(p=0.0000)$ in bacterial counts between sampling sites. The observed transmission of studied opportunistic strains along river course suggests the major point sources for this unique ecosystem were the effluents evacuated from three trout aquacultures.

OPPF counts $\left(0-5 \mathrm{cfu} \cdot \mathrm{mL}^{-1}\right)$ and their percentage in TPFP $(11.2-11.5 \%)$ were lowest in the samples collected in sites I and II in the upper course of the Drweca River. OPPF counts and their percentage in TPFP increased with distance from the river source. In water samples collected directly downstream from fish farms, OPPF counts were highest $\left(30-76 \mathrm{cfu} \cdot \mathrm{mL}^{-1}\right)$ and their proportions in TPFP exceeded $80 \%$. In total, more than $63 \%$ of the strains from all tested OPPF isolates with high hemolytic and proteolytic $(\mathrm{R} \geq 4)$ activity were found in water samples from sites III, V and VI directly downstream from the effluent discharge points of the fishing farms in Czarci Jar and Rychnowska Wola. The highest OPPF counts noted in water of samples collected in V and VI downstream from the fishing farms in Rychnowska Wola corresponded with an increase of river flow rate and some physicochemical water parameters observed in study of the Drweca River [26]. According to Teodorowicz [26] the flow water rates ranged from 0.283 to $0.393 \mathrm{~m}^{3} \cdot \mathrm{s}^{-1}$ at sites situated behind fish farms no. 2 and 3 in Rychnowska Wola. Equally, the highest concentrations of $\mathrm{BOD}_{5}\left(3.2 \pm 1.7 \mathrm{mg} \mathrm{O} \cdot \mathrm{L}^{-1}\right)$, total phosphorus $\left(0.20 \pm 0.07 \mathrm{mg} \mathrm{P} \cdot \mathrm{L}^{-1}\right)$ and ammonia nitrogen $\left(0.18 \pm 0.08 \mathrm{mg} \mathrm{NH} 4-\mathrm{N} \cdot \mathrm{L}^{-1}\right)$ noted in water samples collected downstream from the fishing farms in Rychnowska Wola could have conditioned the growth the OPPF. These findings suggest that effluents from trout aquaculture directly contribute to the prevalence of OPPF in Drwęca and increase the local risk of infection for humans, fish and other living organisms.

The results of the analysis investigating the sensitivity of opportunistic pathogen $P$. fluorescens strains to the most commonly used drugs and disinfectants confirmed that intensive fish farming increases the epidemiological risk in the upper course of Drwęca. Most OPPF isolates were resistant to cefotaxime (71\%) and norfloxacin (52\%), while $46 \%$ of the isolates were resistant to ampicillin (AMC), mezlocillin (MEZ) and tetracycline (TE). Unfortunately, the information regarding the specific types and the amounts of antibiotics used in the three local fish farms over the study period of Drweca River has not been publicly available. Nevertheless, some literature data [42,43] suggest a correlation between findings of increased bacterial resistance levels within and around inland fish farms and the antimicrobial agents used at the farms. On the other hand, Schmidt et al. [44] showed that a simple overall correlation between antibiotic usage and emergence of bacterial antibiotic resistance was not often evident, presumably because the sampling strategy was not always correlated with clinical outbreaks of disease and antibiotic therapy at the farms. According to Pirnay et al. [45], Pseudomonas species are naturally resistant to the penicillins, cephems and rifampin because they have relatively impermeable membranes, inducible efflux systems and chromosomally encoded inducible $\beta$-lactamase. However, antibiotic overuse in treatment and prevention increases drug-resistance also in $P$. fluorescens strains $[6,7,22]$. This observation is supported by the present findings and literature data, which point to different antibiotic resistance profiles of opportunistic pathogens $P$. fluorescens isolated from various aquatic and aquaculture environments. Research into Pseudomonas spp. isolated from 400 samples collected from 100 diseased fish demonstrated that $75 \%$ of the isolates were resistant to standard doses of cefotaxime, but were sensitive to norfloxacin, gentamicin, enrofloxacin, norfloxacin, ciprofloxacin, florfenicol, doxycycline, sulfa-trimethoprim, oxytetracycline, nalidixic acid and streptomycin [5]. Kumar and Surendran [13] analyzed the antibiotic resistance profiles of $P$. fluorescens isolated from brackish water and fresh water aquacultures and found that $100 \%$ of $P$. fluorescens isolates were resistant to oxytetracycline, nitrofurantoin, chloramphenicol and sulfamethizole. However, other studies of fish colonized by $P$. fluorescens isolated from fresh and brackish water demonstrated that oxytetracycline was highly effective against Pseudomon as species, whereas ciprofloxacin was less effective [46].

Among the 63 studied OPPF strains from the Drwęca River, 52\% isolates were characterized by multi-drug resistance and were not sensitive to at least two antibiotics from different groups. These strains were detected in sites III, V and VI downstream from the fishing farms in Czarci Jar and 
Rychnowska Wola in different seasons of the year. However, these samples from different seasons did not present variety in enumeration results of multiple antibiotic resistant OPPF between water samples collected directly downstream from fish farms in Czarci Jar and Rychnowska Wola. The values of the MAR index were higher (0.27-0.51) in the strains isolated from the above sites than in the isolates sampled from sites I, II, IV and VII. The OPPF strains from sites I and II were characterized by the lowest MAR values that did not exceed 0.04, whereas the MAR values of the strains from the samples collected at a distance of around $6 \mathrm{~km}$ from the fish farms (sites IV and VII) were several times higher at 0.20 and 0.45 , respectively. These observations indicate that most strains isolated from sites III to VII originated from high risks sources of contamination where antibiotics are often used [37]. An increase in the MAR value of strains isolated from successive sampling sites on the Drweca River points to the spread of multi-drug resistant OPPF along the river continuum.

An analysis of the sensitivity of OPPF isolates to the minimum inhibitory concentrations (MIC) of cefotaxime and norfloxacin revealed that all strains isolated from sampling sites I and II in the upper course of the river were characterized by the lowest MIC CTX and NOR values $\left(\geq 2 \mu \mathrm{g} \cdot \mathrm{mL}^{-1}\right)$. In turn, more than $50 \%$ of the isolates from water samples collected directly downstream from the fish farms (sites III, V and VI) were characterized by very high MIC CTX and NOR values $\left(\geq 256 \mu \mathrm{g} \cdot \mathrm{mL}^{-1}\right)$. The MIC CTX and NOR values of the tested isolates were correlated with the MIC values of the two tested disinfectants. An analysis of the biocidal efficacy of Steridial (Ste) and chloramine T (Chlor) against OPPF revealed that all strains isolated from sites I and II were also sensitive to the lowest recommended doses of Ste (MIC $\leq 5 \mathrm{~mL} \cdot \mathrm{m}^{-3}$ ) and Chlor (MIC $\left.\leq 2.5 \mathrm{mg} \cdot \mathrm{L}^{-1}\right)$. In turn, most OPPF isolates from water samples collected directly downstream from the fish farms (sites III, V and VI) were resistant to the maximum recommended doses of both disinfectants (MIC Ste $=25 \mathrm{~mL} \cdot \mathrm{m}^{-3}$, MIC Chlor $=20 \mathrm{mg} \cdot \mathrm{L}^{-1}$ ). The observed differences in the counts of OPPF isolates with specific MIC CTX, NOR, Ste and Chlor values between sampling sites were confirmed by the Kruskal-Wallis test $(p \leq 0.05)$ and the agglomerative clustering analysis. Two different clusters were identified based on the counts of OPPF characterized by specific values of MIC STX, NOR, Ste and Chlor. The first cluster consisted of OPPF strains isolated from water samples collected in sites I and II in the upper course of the river, and the second cluster consisted of isolates from sites located directly downstream or at a distance of 6 or $12 \mathrm{~km}$ from the examined fish farms.

\section{Conclusions}

The results of this study indicate that aquaculture effluents exert a significant effect on the concentrations of OPPF and their sensitivity to biocides in the upper course of the Drwecca River, which is a nature and ichthyological reserve. The effluents discharged directly from three fish farms into the analyzed fluvial ecosystem increased in the counts of the examined opportunistic pathogens P. fluorescens (OPPF) and their proportions in the total P. fluorescens population (TPFP) in water samples collected downstream from the investigated fish farms. An analysis of the resistance of OPPF isolates to 12 commonly used antibiotics and two disinfectants confirmed that aquaculture effluents increased the local risk of infection for humans, fish and other living organisms. Most OPPF strains isolated from water samples collected directly downstream from the fish farms were not only resistant to multiple antibiotics (MAR > 0.20), but also to high doses of cefotaxime and norfloxacin (MIC $\geq 256 \mu \mathrm{g} \cdot \mathrm{mL}^{-1}$ ). Most OPPF isolates were also highly resistant to the maximum recommended doses of Steridial (MIC $\geq 25 \mathrm{~mL} \cdot \mathrm{m}^{-3}$ ) and chloramine $\mathrm{T}$ (MIC $\geq 20 \mathrm{mg} \cdot \mathrm{L}^{-1}$ ), which are commonly used in the treatment and prevention of fish diseases in various aquaculture systems. The increase in the abundance of OPPF strains and their resistance to antibiotics and disinfectants (MAR, MIC) in samples of waters from successive sampling sites on the Drwęca River indicates that aquaculture effluents contribute to the spread of multi-drug and disinfectants resistant OPPF along the river continuum. 
Funding: This research received no external funding.

Acknowledgments: This study was supported by research grants No. 18.610-004-300 from the Ministry of Science and Higher Education (Poland). This project was financially supported by the Minister of Science and Higher Education in the range of the program entitled "Regional Initiative of Excellence" for the years 2019-2022, Project No. 010/RID/2018/19, amount of funding 12,000,000 PLN.

Conflicts of Interest: The author declares no conflict of interest. The funders had no role in the design of the study; in the collection, analyses or interpretation of data; in the writing of the manuscript, or in the decision to publish the results.

\section{References}

1. Heinaru, E.; Truu, J.; Stottmeister, U.; Heinaru, A. Three types of phenol and p-cresol catabolism in phenoland p-cresol-degrading bacteria isolated from river water continuously polluted with phenolic compounds. FEMS Microbiol. Ecol. 2000, 31, 195-205. [CrossRef] [PubMed]

2. Palleroni, N.J. Pseudomonas Bacteriology Organisms and Their Biology. In Topley E Wilson's Microbiology and Microbial Infections; John Wiley \& Sons, Ltd.: New York, NY, USA, 2010.

3. Picot, L.; Abdelmoula, S.M.; Merieau, A.; Leroux, P.; Cazin, L.; Orange, N.; Feuilloley, M.G.J. Pseudomonas fluorescens as a potential pathogen: Adherence to nerve cells. Microbes Infect. 2001, 3, 985-995. [CrossRef]

4. Terech-Majewska, E. Improving disease prevention and treatment in controlled fish culture. Arch. Pol. Fish. 2016, 24, 115-165. [CrossRef]

5. Abd El Tawab, A.A.; Ahmed, A.; Maarouf, A.; Nesma, A. Detection of Virulence factors of Pseudomonas species isolated from fresh water fish by PCR. BVMJ 2016, 30, 199-207. [CrossRef]

6. Odjadjare, E.E.; Igbinosa, E.O.; Mordi, R.; Igere, B.; Igeleke, C.L.; Okoh, A.I. Prevalence of multiple antibiotics resistant (MAR) Pseudomonas species in the final effluents of three municipal wastewater treatment facilities in south Africa. Int. J. Environ. Res. Public Health 2012, 9, 2092-2107. [CrossRef] [PubMed]

7. Aich, N.; Naznin, A.; Anirban, A. Issues of antibiotic resistance in aquaculture industry and its way forward. Int. J. Curr. Microbiol. Appl. Sci. 2018, 7, 26-41. [CrossRef]

8. Sidoruk, M.; Cymes, I. Effect of water management technology used in trout culture on water quality in fish ponds. Water 2018, 10, 1264. [CrossRef]

9. Obolewski, K.; Glińska-Lewczuk, K.; Kobus, S. An attempt at evaluating the influence of water quality on the qualitative and quantitative structure of epiphytic fauna dwelling on Stratiotes aloides L., a case study on an oxbow lake of the Łyna River. J. Elementol. 2009, 14, 119-134. [CrossRef]

10. Astel, A.M.; Bigus, K.; Obolewski, K.; Glińska-Lewczuk, K. Spatiotemporal assessment of water chemistry in intermittently open/closed coastal lakes of Southern Baltic. Estuar. Coast. Shelf Sci. 2016, 182, 47-59. [CrossRef]

11. Sidoruk, M.; Koc, J.; Cymes, I.; Rafałowska, M.; Rochwerger, A.; Sobczyńska-Wójcik, K.; Skibniewska, K.A.; Siemianowska, E.; Guziur, J.; Szarek, J. Risk assessment of surface waters associated with water circulation technologies on trout farms. J. Ecol. Eng. 2014, 15, 76-81. [CrossRef]

12. Tkachenko, H.; Kurhaluk, N.; Grudniewska, J. Oxidative stress biomarkers in different tissues of rainbow trout (Oncorhynchus mykiss) exposed to Disinfectant-CIP formulated with per acetic acid and hydrogen peroxide. Arch. Pol. Fish. 2014, 22, 207-219. [CrossRef]

13. Kumar, R.; Surendran, F.K. Phenotypic characterization and antibiotic resistance of Pseudomonas spp. from seafood and aquaculture farm environments. Fish. Technol. 2005, 42, 203-208.

14. Harnisz, M.; Gołaś, I.; Pietruk, M. Tetracycline-resistant bacteria as indicators of antimicrobial resistance in protected waters-the example of the Drwęca River nature reserve (Poland). Ecol. Indic. 2011, 11, 663-668. [CrossRef]

15. Pimentel, G.A.; Almeida, P.; Hantson, A.-L.; Rapaport, A.; Vande Wouwer, A. Experimental validation of a simple dynamic model of a laboratory scale recirculating aquaculture system fitted with a submerged membrane bioreactor. Biochem. Eng. J. 2017, 122, 1-12. [CrossRef]

16. Fossmark, R.O.; Vadstein, O.; Rostend, T.W.; Bakke, I.; Košeto, D.; Bugten, A.V.; Helberg, G.A.; Nesje, J.; Jørgensen, N.O.G.; Raspati, G.; et al. Effects of reduced organic matter loading through membrane filtration on the microbial community dynamics in recirculating aquaculture systems (RAS) with Atlantic salmon parr (Salmo salar). Aquaculture 2020, 524, 735268. [CrossRef] 
17. Summerfelt, S.T.; Sharrer, M.J.; Tsukuda, S.M.; Gearheart, M. Process requirements for achieving full-flow disinfection of recirculating water using ozonation and UV irradiation. Aquac. Eng. 2009, 40, 17-27. [CrossRef]

18. Guardiola, F.A.; Cuesta, A.; Meseguer, J.; Esteban, M.A. Risks of using antifouling biocides in aquaculture. Int. J. Mol. Sci. 2012, 13, 1541-1560. [CrossRef]

19. Research Strategy to Address the Knowledge Gaps on the Antimicrobial Resistance Effects of Biocides. Scientific Committee on Emerging and Newly Identified Health Risks (SCENIHR). 17 March 2010. Available online: https://ec.europa.eu/health/sites/health/files/scientific_committees/emerging/docs/scenihr_ O_028.pdf (accessed on 2 June 2020).

20. Grudniewska, J.; Terech-Majewska, E.; Goral, C. Evaluate the efficacy of the biocidal product in the hatchery during egg incubation and prophylactic bathing rainbow trout (Oncorhynchus mykiss) fry. In Biotechnology in Aquaculture; Zakęś, Z., Wolnicki, J., Demska-Zakęś, K., Kaminski, R., Eds.; Wyd. IRS: Olsztyn, Poland, 2008; pp. 395-401. (In Polish)

21. Terech-Majewska, E.; Grudniewska, J.; Siwicki, A.K. Disinfection with the most effective biocides as a prophylactic method to supplement the treatment of fish diseases. Komun. Ryb 2010, 2, 11-16. (In Polish)

22. Serrano, P.H. Responsible use of antibiotics in aquaculture. In FAO Fisheries Technical Paper 469; Food and Agriculture Organization of the United Nations: Rome, Italy, 2005.

23. European Economic Commission. Council Directive 92/43/EEC of 21 May 1992 on the Conservation of Natural Habitats and of Wild Fauna and Flora; European Economic Commission: Brussels, Belgium, 1992.

24. Ordinance of the Minister of Forestry and Wood Industry of July 27, 1961 regarding recognition as a nature reserve (MP No. 71, item 302).

25. Gołaś, I. Anthropogenic and Environmental Factors Affecting the Bacteriological Quality of the Upper Drwęca River; Wyd. UWM: Olsztyn, Poland, 2011; p. 122. (In Polish)

26. Teodorowicz, M. Surface water quality and intensive fish culture. Arch. Pol. Fish. 2013, 21, 65-111. [CrossRef]

27. APHA. Standard Methods for the Examination of Water and Wastewater, 15th ed.; Water Pollution Control Federation: New York, NY, USA, 1992.

28. Saha, R.S.; Donofrio, D.; Goeres, M.; Bagley, S.T. Rapid detection of rRNA group I pseudomonads in contaminated metalworking fluids and biofilm formation by fluorescent in situ hybridization. Appl. Microbiol. Biotechnol. 2012, 94, 799-808. [CrossRef]

29. Gołaś, I.; Szmyt, M.; Potorski, J.; Łopata, M.; Gotkowska-Płachta, A.; Glińska-Lewczuk, K. Distribution of Pseudomonas fluorescens and Aeromonas hydrophila bacteria in a recirculating aquaculture system during farming of european grayling (Thymallus thymallus L.) Broodstock. Water 2019, 11, 376-391.

30. Rogulska, A.; Antychowicz, J.; Żelazny, J. Haemolytic and proteolytic activity of Aeromonas hydrophila and A. sobria as markers of pathogenicity for carp (Cyprinus carpio L.). Med. Weter. 1994, 50, 55-58.

31. Hsu, T.C.; Waltman, W.D.; Shotts, E.B. Correlation of extracellular enzymatic activity and biochemical characteristics with regard to virulence of Aeromonas hydrophila. Dev. Biol. Stand. 1981, 49, 101-111.

32. Chang, C.I.; Liu, W.Y.; Shyu, C.Z. Use of prawn blood agar hemolysis to screen for bacteria opportunistic to cultured tiger prawns Penaeus monodon. Dis. Aquat. Organ. 2000, 43, 153-157. [CrossRef] [PubMed]

33. Larsen, M.D.; Kristiansen, K.R.; Hansen, T.K. Characterization of the proteolytic activity of starter cultures of Penicillium roqueforti for production of blue veined cheeses. Int. J. Food Microbiol. 1998, 43, $215-221$. [CrossRef]

34. Bauer, A.W.; Kirby, W.N.M.; Sherris, J.C.; Turck, M. Antibiotic susceptibility testing by a standardized single disk method. An. J. Clin. Pathol. 1966, 45, 493-496. [CrossRef]

35. Clinical and Laboratory Standards Institute (CLSI). Performance Standards for Susceptibility Tests; Approved Standard, 11th ed.; CLSI document: M02-A11; Clinical and Laboratory Standards Institute (CLSI): Wayne, PA, USA, 2012.

36. Krumperman, P.H. Multiple antibiotic resistance indexing of Escherichia coli to identify high-risk sources of fecal contamination of food. Appl. Environ. Microb. 1983, 46, 165-170. [CrossRef]

37. Paul, S.L.; Bezbaruah, R.L.; Roy, M.K.; Ghosh, A.C. Multiple antibiotic resistance index and its reversion in Pseudomonas aeruginosa. Lett. Appl. Microbiol. 1997, 24, 169-171. [CrossRef]

38. Baker, C.N.; Stocker, S.A.; Culver, D.H.; Thornsberry, C. Comparison of the E test to agar dilution, broth microdilution, and agar diffusion susceptibility testing techniques by using a special challenge set of bacteria. J. Clin. Microbiol. 1991, 29, 533-538. [CrossRef] 
39. Stanisz, A. A straightforward course in statistics based on the STATISTICA PL program as applied in medicine. In Volume Basic Statistics; StatSoft: Cracow, Poland, 2006; ISBN 83-88724-18-5. (In Polish)

40. Madi, A.; Lakhdari, O.; Blottière, H.M.; Guyard-Nicodeme, M.; Le Roux, K.; Groboillot, A.; Svinareff, P.; Doré, J.; Orange, N.; Feuilloley, M.G.J.; et al. The clinical Pseudomonas fluorescens MFN1032 strain exerts a cytotoxic effect on epithelial intestinal cells and induces Interleukin-8 via the AP-1 signaling pathway. BMC Microbiol. 2010, 10, 215-222. [CrossRef]

41. Trivedi, M.K.; Patil, S.; Shettigar, H.; Gangwar, M.; Jana, S. Antimicrobial Sensitivity Pattern of Pseudomonas fluorescens after Biofield Treatment. J. Infect. Dis. Ther. 2015, 3, 222-226. [CrossRef]

42. Mirand, C.D.; Zemelman, R. Antimicrobial multiresistance in bacteria isolated from freshwater Chilean salmon farms. Sci. Total Environ. 2002, 293, 207-218. [CrossRef]

43. Spanggaard, B.; Jørgensen, F.; Gram, L.; Huss, H.H. Antibiotic resistance in bacteria isolated from three freshwater fish farms and an unpolluted stream in Denmark. Aquaculture 1993, 115, 195-207. [CrossRef]

44. Schmidt, A.S.; Bruun, M.S.; Dalsgaard, I.; Pedersen, K.; Larsen, J.L. Occurrence of antimicrobial resistance in fish-pathogenic and environmental bacteria associated with four Danish rainbow trout farms. Appl. Environ. Microbiol. 2000, 66, 4908-4915. [CrossRef]

45. Pirnay, J.-P.; Matthijs, S.; Colak, H.; Chablain, P.; Bilocq, F.; van Eldere, J.; de Vos, D.; Zizi, M.; Triest, L.; Cornelis, P. Global Pseudomonas aeruginosa biodiversity as reflected in a Belgian river. Environ. Microbiol. 2005, 7, 969-980. [CrossRef]

46. Kholil, M.I.; Hossain, M.M.M.; Neowajh, M.S.; Islam, M.S.; Kabir, M. Comparative efficiency of some commercial antibiotics against Pseudomonas infection in fish. Int. J. Fish. Aquat. Stud. 2015, 2, 114-117.

(C) 2020 by the author. Licensee MDPI, Basel, Switzerland. This article is an open access article distributed under the terms and conditions of the Creative Commons Attribution (CC BY) license (http://creativecommons.org/licenses/by/4.0/). 